\title{
HAEMAGGLUTINATION ACTIVITY OF LECTINS FROM EXTRACTS OF SOME VIETNAM MARINE SPONGES
}

\author{
Le Dinh Hung ${ }^{\bowtie}$, Dinh Thanh Trung
}

Nha Trang Institute of Technology Research and Application, Vietnam Academy of Science and Technology

${ }^{\circledR}$ To whom correspondence should be addressed. E-mail: ledinhhungims@yahoo.co.uk

Received: 02.10.2019

Accepted: 25.12.2019

SUMMARY

\begin{abstract}
Aqueous extracts from 16 species of Vietnam marine sponges were examined for haemagglutination activity using native and enzyme-treated different animal and human erythrocytes. Among these, extracts from 14 species were found to have haemagglutinination activities toward at least one type of erythrocyte tested meaning that $87.5 \%$ of the surveyed marine sponge species possess haemagglutination activity. Strong activity was detected in extracts from marine sponge species Acanthella cavernosa, Axinyssa sp., Cinachyrella sp., 01NT.2.4, 3.5, 3.10, 3.11 and 3.18 with enzyme-treated various animal and human erythrocytes. In a haemagglutination-inhibition test with various monosaccharides and glycoproteins, haemagglutination activity of the extract from A. cavernosa had no affinity for any of the monosaccharides, but inhibited by porcine stomach mucin and fetuin, whereas activities of the extract from Cinachyrella sp. were strongly inhibited by monosaccharides, such as D-galactose and N-acetyl-D-galatosamine, but not with glycoproteins. The activity of Stylissa flexibilis extract was inhibited by D-galactose, porcine stomach mucin, fetuin and their asialo derivatives, suggesting the presence of lectin specific for O-glycans of this species. The activities of four sponge extracts from A. cavernosa, S. flexibilis, Axinyssa sp. and Cinachyrella sp. were stable over a wide range of $\mathrm{pH}$ and temperature. Haemagglutination activities of A. cavernosa, Axinyssa sp. and Cinachyrella sp. extracts were independent of the presence of divalent cations, except for the haemagglutination activity of extract from S. flexibilis, which was dependent on the presence of divalent cations. The results suggest that Vietnam marine sponges may be good sources of useful lectins for biochemical and biomedical applications.
\end{abstract}

Keywords: carbohydrate-binding specificity, haemagglutination activity, lectins, marine sponge

\section{INTRODUCTION}

Lectins, or carbohydrate-binding proteins, are present in various organisms from viruses to mammals and serve as recognition molecules between cells, cell and matrix, and organisms. Owing to the capability of discriminating carbohydrate structures, not only are lectins used as valuable biochemical reagents in many research fields, including glycomics, but they are promising candidates for medicinal and clinical application (Sharon, Lis, 2003).

Marine sponges are primitive metazoans capable of producing a large amount of compounds that protect them both from undesirable predators as well as from infection by other pathogens (Sepcic et al., 2010). The first description of lectin from marine sponges was conducted by Dodd et al. (1968). Later, the 48 sponge species collected in the Barrier Reef of Australia and the Florida Keys was evaluated for haemagglutination capacity. The results showed that $42 \%$ of species had lectins capable of haemagglutinating erythrocytes (Mebs et al., 1985). More than a decade later, 22 species of tropical sponges collected in the Los Roques NationalPark (Venezuela) were analyzed and the haemagglutination activity was found in 10 of the species tested (Miarons, Fresno, 2000). Recently, a large number of lectins from marine sponges that possess various biochemical characteristics have been purified and identified including: galectins, Ctype, tachylectin-like and F-type lectins (Garderes et al., 2015). Like other natural products isolated from marine organisms, lectins from marine sponges have shown great potential as candidates for new drugs, due to their wide range of biological activities, such 
as pro-inflammatory (Queiroz et al., 2008), mitogenic (Atta et al., 1989; Bretting et al., 1981a; Xiong et al., 2006; Dresch et al., 2012), chemotactic (Dresch et al., 2008), antibacterial (Schröder et al., 2003; Kawsar et al., 2011) and anticancer activities (Queiroz et al., 2009; Dresch et al., 2013; Garderes et al., 2015; Filho et al., 2015). Thus, marine sponges may be dominant sources of useful lectins for applications against bacteria and tumor cells.

Vietnam is located in the tropical and subtropical zone with a long coast line of about $3,260 \mathrm{~km}$ where there is a rich marine biodiversity of algae, invertebrates, sponges, bacteria, viruses and so on. Such species may be potential sources for studies and application of lectins. However, only little information is known about lectins from Vietnam marine organisms, except several reports on the hemagglutinins from Vietnamese marine algae and invertebrates (Le Dinh Hung et al., 2009a, 2012; Dinh Thanh Trung et al., 2017; Cao Đang Nguyen, 1998; Cao Đang Nguyen, Nguyen Quoc Khang, 1998), lectins from the red algae Kappaphycus alvarezii, Kappaphycus striatum, Eucheuma denticulatum, Gracilaria salicornia , Hydropuntia eucheumatoides (Le Dinh Hung et al., 2009b, 2011, 2013, 2015a, 2018a) and from marine sponge Stylissa flexibilis (Le Dinh Hung et al., 2018b), the cDNA clones encoding lectins from $K$. striatum and E. denticulatum (Le Dinh Hung et al., 2015a, 2015b, 2016) and seasonal variations in lectin contents from the cultivated red algae $K$. alvarezii and $K$. striatus (Le Dinh Hung et al., 2009c, 2019). Thus, the objective of this research was to screen and characterize lectin from the extracts of Vietnam marine sponges, which will provide more valuable information for future applications.

\section{MATERIALS AND METHODS}

\section{Materials}

Sixteen specimens of marine sponges were collected at Khanh Hoa province of Vietnam from July, 2015 to May, 2016. After collection, they were immediately transferred to the laboratory on ice and kept at $-20^{\circ} \mathrm{C}$ until used. The marine sponge samples were collected and identified by MSc. Thai Minh Quang - Institute of Oceanography, Vietnam. Blood from rabbit, sheep and horse was obtained from the Institute of Vaccine Nha Trang, Vietnam. Human A, $\mathrm{B}$, and $\mathrm{O}$ bloods were obtained from Blood transfusion and Hematology Center of Khanh Hoa
General Hospital, Vietnam. Transferrin, fetuin, porcine thyroglobulin, porcine stomach mucin (Type III), D-glucose, D-mannose, D-galactose, N-acetylD-glucosamine, N-acetyl-D-mannosamine, N-acetylD-galactosamine and Tris (hydroxymethyl)aminomethane (Tris) were purchased from Sigma Chemical Co. Yeast mannan and $\mathrm{N}$-acetylneuraminic acid were obtained from Nakarai Chemical Co.

Preparations of marine sponge extracts and ammonium sulfate precipitates

A $20 \mathrm{~g}$ sample of each sponge was cut into small pieces, homogenized in a blender with 2 volumes of Tris- $\mathrm{HCl}$ buffer $20 \mathrm{mM}$, pH 7.5 containing $\mathrm{NaCl} 150$ $\mathrm{mM}$ (TBS), and kept at $4^{\circ} \mathrm{C}$ for $12 \mathrm{~h}$ with occasionally stirring. After filtration through a cheese cloth, the filtrate was centrifuged at 10,000 $\mathrm{rpm}$ for $30 \mathrm{~min}$. The supernatants were recovered and stored at $-20^{\circ} \mathrm{C}$ until used. Haemagglutination tests were carried out with erythrocytes of various human and animals in a native state or enzymetreated with trypsin and papain. To the supernatant (extract), solid ammonium sulfate was slowly added to attain $75 \%$ saturation. The mixture was gently stirred and then kept at $4^{\circ} \mathrm{C}$ for $18 \mathrm{~h}$. Precipitates were recovered by centrifugation at $10,000 \mathrm{rpm}$ for $20 \mathrm{~min}$, dissolved in a small volume of TBS, and thoroughly dialyzed against the same buffer. The non-dialyzable fraction was recovered as an ammonium sulfate-precipitate. The ammonium sulfate-precipitates obtained were used for both haemagglutination-inhibition and stability tests (Kawsar et al., 2008).

\section{Preparation of a $2 \%$ suspension of native or enzyme-treated erythrocytes}

Each blood sample was washed from three to five times with 50 volumes of saline. After washing, a $2 \%$ erythrocyte suspension $(\mathrm{v} / \mathrm{v})$ was prepared in saline and used as native erythrocytes. trypsin- or papain-treated erythrocytes were prepared as follows. One-tenth volume of $0.5 \%(\mathrm{w} / \mathrm{v})$ trypsin or papain solution was added to a $2 \%$ native erythrocyte suspension, and the mixture was incubated at $37^{\circ} \mathrm{C}$ for $60 \mathrm{~min}$. After incubation, the erythrocytes were washed from three to five times with saline and a $2 \%$ suspension $(\mathrm{v} / \mathrm{v})$ of trypsin- or papain-treated erythrocytes was prepared in saline (Le Dinh Hung et al., 2009a).

\section{Haemagglutination assay}

Haemagglutination assays were carried out using 
a microtiter method in a 96-well microtiter V-plate (Le Dinh Hung et al., 2009a). Firstly, $25 \mu$ of serially two-fold dilutions of a test solution were prepared in saline on a microtiter V-plate. To each well, $25 \mu$ of a $2 \%$ erythrocyte suspension was added and the mixtures gently shaken and incubated at room temperature for $2 \mathrm{~h}$. A positive result was indicated by formation of a uniform layer of coagulant over the surface of the well. On the other hand, a negative test result was indicated by the formation of a discrete "button" at the bottom of the well. Haemagglutination activity was expressed as a titer, the reciprocal of the highest two-fold dilution exhibiting positive haemagglutination. The assay was carried out in triplicate for each test solution.

\section{Haemagglutination-inhibition test}

Hemagglutination-inhibition tests were carried out according to the method previously described (Le Dinh Hung et al., 2009a). Firstly, $25 \mu \mathrm{L}$ of serially two-fold dilutions of sugar or glycoprotein were prepared in saline. To each well, an equal volume of extract solution with a haemagglutination titer of four was added, and the plate was mixed gently and allowed to stand at room temperature for 1 h. Finally, $25 \mu \mathrm{L}$ of a $2 \%$ suspension of trypsintreated rabbit erythrocytes was added to each well, and the plate gently shaken and incubated for a further $1 \mathrm{~h}$. Inhibition was observed macroscopically and inhibition activity was expressed as the lowest concentration of sugar or glycoprotein at which complete inhibition of haemagglutination was achieved. The assay was performed in duplicate per sugar and glycoprotein. Asialo-transferrin, asialofetuin and asialo-porcine stomach mucin were prepared by hydrolyses of their parent sialo glycoproteins with $0.05 \mathrm{M} \mathrm{HCl}$ for $1 \mathrm{~h}$ at $80^{\circ} \mathrm{C}$ followed by dialysis against saline overnight.

\section{Effects on haemagglutination activity of divalent cations, $\mathrm{pH}$, and temperature}

To examine the effect of temperature, a $1 \mathrm{~mL}$ aliquot of an extract solution was heated at various temperatures $\left(30-100^{\circ} \mathrm{C}\right)$ for $30 \mathrm{~min}$, then immediately cooled on ice, and haemagglutination activity was determined. To examine the effect of $\mathrm{pH}$, a $1 \mathrm{~mL}$ aliquot of an extract solution was dialyzed at $4^{\circ} \mathrm{C}$ overnight against $0.05 \mathrm{M}$ buffers of various $\mathrm{pH}$ from 3 to 10 and then dialyzed against saline to eliminate the $\mathrm{pH}$ effect. The non-dialyzable fractions were assayed for haemagglutination activity. The following buffers were used; acetate buffer for $\mathrm{pH}$ from 3 to 5 , Tris- $\mathrm{HCl}$ buffer for $\mathrm{pH}$ from 6 to 10 . To examine the effects of divalent cations on haemagglutination activity, a $1 \mathrm{~mL}$ aliquot of an extract solution was dialyzed at $4{ }^{\circ} \mathrm{C}$ overnight against $100 \mathrm{~mL}$ of $50 \mathrm{mM}$ EDTA in TBS. The nondialyzable fraction was recovered and haemagglutination activity in the presence or absence of divalent cation $\left(\mathrm{CaCl}_{2}\right)$ was determined. Haemagglutination activity was determined with trypsin-treated rabbit erythrocytes (Le Dinh Hung et al., 2009a).

\section{RESULTS AND DISCUSSION}

The extract amount from marine sponge samples agglutinated the different types of erythrocytes expressed as \% (Figure 1). Rabbit erythrocytes showed the most detection of the haemagglutination activity with $68 \%$ of crude extracts, following human $\mathrm{A}$ and $\mathrm{O}$ blood erythrocytes agglutinated with $62,5 \%$ of crude extracts, sheep and human B blood erythrocytes showed the agglutination with $50 \%$ and $43.5 \%$ of crude extracts, respectively, horse erythrocytes showed the lowest agglutination with $37.5 \%$ of crude extracts.

Of the 16 marine sponge species surveyed, extracts from 14 species agglutinated at least one type of erythrocytes tested (Table 1). Extracts from Acanthella cavernosa, Axinyssa sp., Cinachyrella sp., 01NT.2.4, 3.5, 3.10, 3.11 and 3.28 showed stronger agglutination activities with enzymetreated rabbit, sheep and horse erythrocytes than with human A, B and O blood erythrocytes. Extracts from species 3.9 and 3.36 showed no haemagglutination with any erythrocyte types tested. Extracts from species 01NT.2.4 had relatively activities with enzyme-treated animal erythrocytes, but no haemagglutination was observed with the types of human erythrocytes irrespective of treatment with enzymes. In particular, the extract from Stylissa flexibilis showed only agglutination with enzyme-treated human A blood erythrocytes, whereas it did not agglutinate any type of rabbit, sheep, horse, human $\mathrm{B}$ and $\mathrm{O}$ erythrocytes. The similar results have been reported for haemagglutination activity from marine sponges collected in the Caribbean Sea (Miarons, Fresno, 2000) and at the Red Sea, coast of Jordan south of Aqaba (Mebs et al., 1985), which showed some haemagglutination activity against human A, B and $\mathrm{O}$ blood group cells tested. 


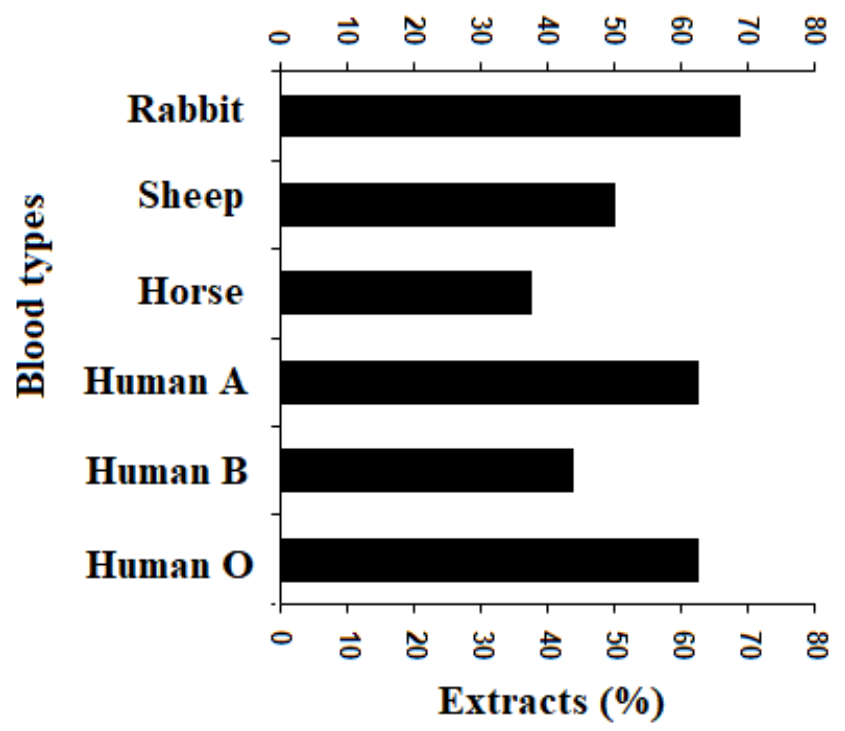

Figure 1. The extract amount agglutinated the different types of erythrocytes expressed as $\%$.

Table 1. Haemagglutination activity of extracts from some Vietam marine sponges.

\begin{tabular}{|c|c|c|c|c|c|c|c|c|c|c|c|c|c|c|c|c|c|c|}
\hline \multirow[t]{3}{*}{ Species } & \multicolumn{18}{|c|}{ Haemagglutination titer of marine sponge extracts ${ }^{a}$} \\
\hline & \multicolumn{3}{|c|}{ Rabbit } & \multicolumn{3}{|c|}{ Sheep } & \multicolumn{3}{|c|}{ Horse } & \multicolumn{3}{|c|}{ Human A } & \multicolumn{3}{|c|}{ Human B } & \multicolumn{3}{|c|}{ Human $\mathrm{O}$} \\
\hline & $\mathbf{N}^{\mathrm{b}}$ & $\mathbf{T}^{\mathrm{c}}$ & $P^{d}$ & $\mathbf{N}^{\mathbf{b}}$ & $\mathbf{T}^{\mathrm{c}}$ & $P^{d}$ & $\mathbf{N}^{\mathrm{b}}$ & $\mathbf{T}^{\mathrm{c}}$ & $P^{d}$ & $\mathbf{N}^{\mathbf{b}}$ & $\mathrm{T}^{\mathrm{c}}$ & $P^{d}$ & $\mathbf{N}^{\mathrm{b}}$ & $\mathrm{T}^{\mathrm{c}}$ & $P^{d}$ & $\mathbf{N}^{\mathbf{b}}$ & $\mathbf{T}^{\mathrm{c}}$ & $P^{d}$ \\
\hline $\begin{array}{l}\text { Aaptos } \\
\text { suberitoides }\end{array}$ & 2 & 4 & 4 & 8 & 16 & 8 & 64 & 512 & 512 & 8 & 32 & 32 & 16 & 128 & 128 & 32 & 32 & 32 \\
\hline $\begin{array}{l}\text { Haliclona } \\
\text { sp. }\end{array}$ & 32 & 32 & 64 & 4 & 8 & 16 & $-{ }^{e}$ & - & - & 8 & 64 & 64 & 8 & 32 & 64 & 64 & 64 & 64 \\
\hline $\begin{array}{l}\text { Acanthella } \\
\text { cavernosa }\end{array}$ & 512 & 512 & 512 & 128 & 128 & 256 & 4 & 16 & 16 & 64 & 128 & 128 & 32 & 128 & 128 & 32 & 64 & 64 \\
\hline $\begin{array}{l}\text { Haliclona } \\
\text { amboinensis }\end{array}$ & - & - & - & 2 & 2 & 8 & - & - & - & - & - & - & - & - & 16 & - & - & 8 \\
\hline Axinyssa sp. & 128 & 512 & 1024 & - & - & - & - & - & - & 32 & 128 & 128 & 32 & 64 & 128 & 32 & 64 & 64 \\
\hline Stylissa sp. & - & - & - & - & - & - & 32 & 32 & 32 & - & - & - & - & - & - & - & - & - \\
\hline $\begin{array}{l}\text { Cinachyrella } \\
\text { sp. }\end{array}$ & 512 & 1024 & 1024 & - & - & - & 16 & 2 & 32 & 4 & 8 & 8 & - & - & - & - & - & - \\
\hline 01NT.2.4 & 128 & 1024 & 1024 & 32 & 256 & 1024 & - & - & - & - & - & - & - & - & - & - & - & - \\
\hline $\begin{array}{l}\text { Stylissa } \\
\text { flexibilis }\end{array}$ & - & - & - & - & - & - & - & - & - & - & 64 & 64 & - & - & - & - & - & - \\
\hline 3.2 & 64 & 256 & 256 & - & - & - & 16 & 32 & 32 & 8 & 16 & 16 & - & - & - & 8 & 16 & 16 \\
\hline 3.5 & 512 & 1024 & 1024 & - & - & - & - & - & - & - & - & - & - & - & - & 4 & 8 & 8 \\
\hline 3.9 & - & - & - & - & - & - & - & - & - & - & - & - & - & - & - & - & - & - \\
\hline 3.10 & 512 & 1024 & 1024 & - & 2 & 4 & - & - & - & 2 & 8 & 8 & 4 & 16 & 16 & 8 & 16 & 16 \\
\hline 3.11 & 64 & 1024 & 1024 & 4 & 16 & 16 & - & - & - & 4 & 8 & 8 & - & - & - & 4 & 16 & 16 \\
\hline 3.28 & 64 & 2048 & 2048 & 64 & 128 & 128 & 16 & 32 & 64 & 16 & 32 & 32 & 16 & 32 & 32 & 8 & 32 & 32 \\
\hline 3.36 & - & - & - & - & - & - & - & - & - & - & - & - & - & - & - & - & - & - \\
\hline
\end{tabular}

${ }^{a}$ Hemagglutination activity was expressed as a titer, the reciprocal of the highest dilution showing positive hemagglutination.

${ }^{\mathrm{b}}$ Native erythrocytes; ${ }^{\mathrm{c}}$ Trypsin-treated erythrocytes; ${ }^{\mathrm{d}}$ Papain-treated erythrocytes; ${ }^{\mathrm{e}}$ Negative agglutination.

- Species of 01NT.2.4; 3.2; 3.5; 3.9; 3.10; 3.11; 3.28 and 3.16 are not identified yet.

- Significant differences $(P<0.05)$ in haemagglutination activity of the extracts between different erythrocytes were found. 


\section{Carbohydrate binding specificities}

From the 4 active species, carbohydrate-binding specificity of each extract was examined for haemagglutination-inhibition test with a series of sugars and glycoproteins using ammonium sulfate precipitates prepared from each extract (Table 2). The haemagglutination activity of the extract from Axinyssa sp. was strongly inhibited by monosaccharides containing acetamido groups at $\mathrm{C} 2$ position, such as N-acetyl-D-mannosamine, $\mathrm{N}$-acetylD-glucosamine, N-acetyl-D-galatosamine and $\mathrm{N}$ acetyl neuraminic acid. The haemagglutination activity of the extract from $A$. cavernosa was not inhibited by any monosaccharides tested, but inhibited by glycoproteins and their asialo derivative, such as porcine stomach mucin bearing O-glycans and fetuin bearing $\mathrm{N}$-glycans. The haemagglutination activity of the extract from Cinachyrella sp. was strongly inhibited by $\mathrm{N}$-acetyl-D-galatosamine, indicating that this sponge species contain, at least, a lectin specific for N-acetyl-D-galatosamine. The haemagglutination activity of the extracts from 4 sponge species was not inhibited by glycoproteins bearing high mannose, complex and hybrid type N-glycans, such as transferrin, thyroglobulin and yeast manan. The haemagglutination activity of the extract from $S$. flexibilis was inhibited by D-galactose and porcine stomach mucin and its asialo derivative. In fact that elimination of sialic acid residues from porcine stomach mucin increased inhibitory potential of parental glycoprotein, clearly indicating that the presence of $\mathrm{N}$-acetylneuraminic acid (NeuAc) as a terminal residue of the carbohydrate chains affected the haemagglutination activity of $S$. flexibilis. Fetuin bearing both complex type N-glycans and O-glycans were inhibitory. Elimination of sialic acid residues of this glycoprotein increased inhibitory potential of parental glycoprotein. The data suggest that extract from $S$. flexibilis recognized preferentially the terminal alactose residues in porcine stomach mucin and this sponge species contains, at least, a lectin specific for O-glycans. Inhibition by D-galactose has been reported for lectins from marine sponges, such as lectins from Aphrocallistes vastus (Gundacker et al., 2001), Axinella dissimilis (Bretting et al., 1981b), Cinachyrella alloclada (Atta et al., 1989), C. varians (Moura et al., 2006), Desmapsama anchorata (Atta et al., 1990), Halichondria okadai (Kawsar et al., 2008), Haliclona cratera (Pajic et al., 2002), P. semitubulosa (Engel et al., 1992), Axinella polypoides (Bretting, Königsmann, 1976), Chondrilla nucula (Schröder et al., 1990), A. archeri and A. lacunose (Miarons, Fresno, 2000), Axinella corrugate (Dresch et al., 2012) and H.okadai (Kawsar et al., 2011).

Table 2. Haemagglutination-inhibition test otheextracts from marine sponges with sugars and glycoproteins.

\begin{tabular}{lllll}
\hline Sugars and glycoproteins & \multicolumn{4}{c}{ Species } \\
\cline { 2 - 5 } & Stylissa flexibilis & Axinyssa sp. & $\begin{array}{l}\text { Acanthella } \\
\text { cavernosa }\end{array}$ & Cinachyrella sp. \\
\hline Sugars $(m M)$ & & & - & - \\
D-mannose & a & - & - & - \\
D-glucose & - & - & - & 100,0 \\
D-galactose & 6.25 & - & - & - \\
N-acetyl-D-mannosamine & - & 6,25 & - & - \\
N-acetyl-D-glucosamine & - & 12,5 & - & - \\
N-acetyl-D-galatosamine & - & 12,5 & - & - \\
N-acetyl neuraminic acid & - & 25,0 & & - \\
Glycoproteins $(\mu g / m L)$ & & & 500,0 & - \\
Porcine stomach mucin & 500,0 & 1000,0 & 1000,0 & - \\
Asialo-porcine stomach mucin & 62.5 & 1000,0 & 1000,0 & - \\
Trypsin-treated Porcine stomach mucin & 500,0 & 1000,0 & 1000,0 & - \\
Fetuin & 500,0 & - & 250,0 & - \\
Asialo-fetuin & 62,5 & - & - & - \\
Transferin & - & - & - & - \\
Asialo-transferin & - & - & - & \\
Yeast Mannan & - & - & - & \\
Thyroglobulin & - & - & - & - \\
\hline
\end{tabular}

- ${ }^{\text {a }}$ Indicates no inhibition at $100 \mathrm{mM}$ for monosaccharides and at $2000 \mu \mathrm{g} / \mathrm{mL}$ for glycoproteins.

- Significant differences $(P<0.05)$ in haemagglutination inhibition test of the extracts between different sugars and glycoproteins were found. 
Lectins with affinity for galactose appear to have important roles in modulating immune responses in marine animals (Yousif et al., 1994; Mistry et al., 2001; Kurata, Hatai, 2002). Futhermore, inhibition by asialofetuin has been evidenced for lectins from marine sponges, such as HOL-30 from $H$. okadai (Kawsar et al., 2008) and HcL from Haliclona cratera (Pajic et al., 2002). On the other hand, inhibition by porcine stomatch mucin and their asialo derivatives bearing $\mathrm{O}$-glycans that is related to galactose binding specificity has been reported for many lectins from marine sponges, such as CauL from Craniella australiensis (Xiong et al., 2006), Halilectin 2 and Halilectin 3 from Haliclona caerulea (Carneiro et al., 2013a, 2013b), ACL-II from $A$. corrugata (Dresch et al., 2012), HcL from Haliclona crater (Pajic et al., 2002) and AaL from $A$. archeri (Miarons, Fresno, 2000).The inhibition profiles with monosaccharides and glycoproteins were different depending on marine sponge species.

\section{Effects of temperature, $\mathrm{pH}$ and divalent cation on haemagglutination activity}

The effects of temperature, $\mathrm{pH}$ and divalent cations on haemagglutination activity of the extracts from four active species listed in Table 2 were examined. As shown in Figure 2a, the haemagglutination activities of $A$. cavernosa and Cinachyrella sp. extracts were unchanged even when heated at $50^{\circ} \mathrm{C}$ for $30 \mathrm{~min}$. However, their activities were significantly decreased as the incubation temperature exceeded $50^{\circ} \mathrm{C}$ and were completely lost by heating at $70^{\circ} \mathrm{C}$ for $30 \mathrm{~min}$. The

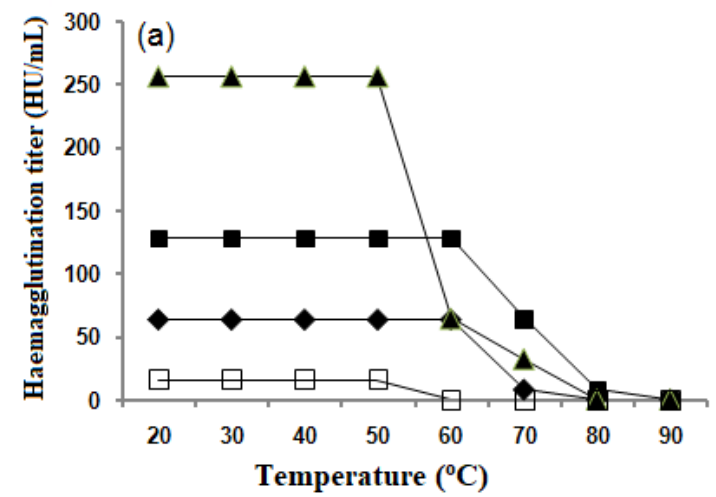

haemagglutination activities of Axinyssa sp. and $S$. flexibilis extracts were stable up to even when heated at $60^{\circ} \mathrm{C}$ for $30 \mathrm{~min}$ and were significantly decreased as the incubation temperature exceeded $60^{\circ} \mathrm{C}$. Most of the marine sponge extracts examined maintained their activities over a wide range of $\mathrm{pH}$ values between 5 and 8 with a slight decrease in activity in more alkaline media, except for activity of Axinyssa sp. extract was unchanged at a $\mathrm{pH}$ range between 4 and 8 (Figure 2b). Many lectins from marine sponges have also been reported for stability from 20 to $70^{\circ} \mathrm{C}$ and at a $\mathrm{pH}$ ranging from 5 to 8 (Gardères et al., 2015).

The haemagglutination activities of extracts from A. cavernosa, Axinyssa sp. and Cinachyrella sp. were unchanged after being dialyzed against $50 \mathrm{mM}$ EDTA and in the presence of $10 \mathrm{mM} \mathrm{CaCl}_{2}$, indicating that haemagglutination activities of these extracts were not dependent on the presence of divalent cations. On the contrary, the haemagglutination activity of extract from $S$. flexibilis was decreased after being dialyzed by EDTA. Addition of $\mathrm{CaCl}_{2}$ at $20 \mathrm{mM}$ concentration restored almost the total haemagglutination activity initially (Figure 3), indicating that biological activity of this lectin was dependent on divalent cations.

The biological activities depending on divalent cations have been reported for lectins from marine sponges, such as lectins from Suberites domuncula (Schröder et al., 2006), Aplysina archeri and $A$. lacunose (Miarons, Fresno, 2000), Cliona varians (Moura et al., 2006) and Pellina semitubulosa (Engel et al., 1992).

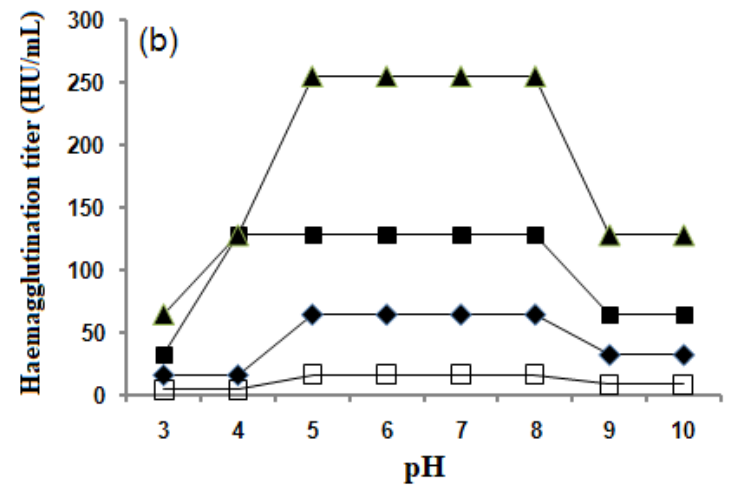

Figure 2. Effects of temperature (a) and $\mathrm{pH}$ (b) on haemagglutination activities of ammonium sulfate precipitates prepared from marine sponges $A$. cavernosa ( $-\mathbf{A})$, Axinyssa sp. (-), S. flexibilis $(-)$ and Cinachyrella sp. ( $\square)$ ). Significant differences $(P<0.05)$ in haemagglutination activities of the extracts between different temperatures and pHs were found. 


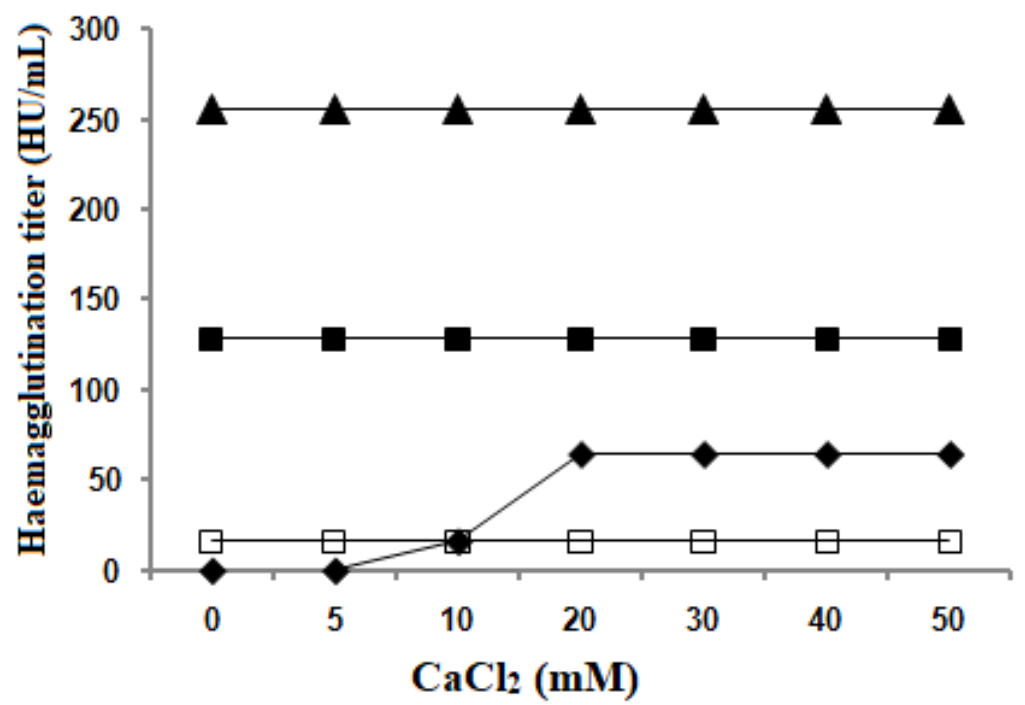

Figure 3. Effects of divalent cation $\left(\mathrm{CaCl}_{2}\right)$ on haemagglutination activities of ammonium sulfate precipitates prepared from marine sponges A. cavernosa $(-\mathbf{-})$, Axinyssa sp. (-), S. flexibilis (-) và Cinachyrella sp. ( $\square)$. Significant differences $(\mathrm{P}<0.05)$ in haemagglutination activities of the extracts between different concentration of $\mathrm{CaCl}_{2}$ were found.

\section{CONCLUSION}

16 species of Vietnam marine sponges were examined for haemagglutination activity using native and enzyme-treated different animal and human erythrocytes. Among these, extracts from 14 species were found to have haemagglutination activity toward at least one type of erythrocyte tested meaning that $87.5 \%$ of the surveyed marine sponge species possess haemagglutination activity. The haemagglutination-inhibition tests indicated that extract from Stylissa flexibilis contains, at least, a lectin specific for O-glycans. On the other hand, haemagglutination activities of four marine sponge extracts were stable over a wide range of $\mathrm{pH}$ and temperature. Thus, Vietnam marine sponges could be promising sources of useful lectins for applications. Results obtained in the present study would be helpful for identification of new lectins and for clarification of the biological significance. Isolation and characterization on lectins from these marine sponges are currently underway.

Acknowledgements: This research was supported by Vietnam Academy of Science and Technology (VAST) under grant numberVAST06.04/16-17. The authors wish to thank MSc. Thai Minh Quang Institute of Oceanography, Vietnam for the identification of marine sponge samples.

\section{REFERENCES}

Atta AM, Barral-Netto M, Peixinho S, Sousa-Atta ML (1989) Isolation and functional characterization of a mitogenic lectin from the marine sponge Cinachyrella alloclada. Braz J Med Biol Res 22: 379-385.

Atta AM, Menezes EP, Peixinho S, Sousa-Atta MLB (1990) Isolation of a lectin fromthe marine sponge Desmapsama anchorata by affinity chromatography on raffinose-Sepharose 6B. Braz J Med Biol Res 23: 191-194.

Bretting H, Kabat EA (1976) Purification and characterization of the agglutinins from the sponge Axinella polypoides and a study of their combining sites. Biochemistry 15: 3228-3236.

Bretting H, Phillips SG, Klumpart HJ, Kabat EAA (1981a) Mitogenic lactose binding lectin from the sponge Geodia cydonium. J Immunol 127: 1652-1658.

Bretting H, Donadey C, Vacele J, Jacobs G (1981b) Investigation on the occurrence of lectins in marine sponges with special regard to some species ofthe family Axinellidae. Comp Biochem Physiol B 70: 69-76.

Cao Đăng Nguyên (1998) Điều tra lectin từ các mẫu sinh vật thường gặp ở vùng biển Hải Hậu. Tạp chi Sinh học 20: 122-127.

Cao Đăng Nguyên, Nguyễn Quốc Khang (1998) Tinh sạch, hoạt tính sinh học và khả năng phản ứng tế bào của lectin trai tai tượng (Tridacna elongata). Tạp chi Di truyền hoc và Úng dụng 2: 32-35. 
Carneiro RF, de Melo AA, Nascimento FEPD, Simplicio CA, Nascimento KS, Rocha BAMD, Saker-Sampaio S, Moura RDM, Mota SS, Cavada BS (2013a) Halilectin 1 (H-1) and Halilectin $2(\mathrm{H}-2)$ : Two new lectins isolated from the marine sponge Haliclona caerulea. $J$ Mol Recognit 26: 51-58.

Carneiro RF, de Melo AA, de Almeida AS, Moura RM, Chaves RP, de Sousa R,Nascimento KS, Sampaio SS, Lima JP, Cavada BS (2013b) H-3, a new lectin from the marine sponge Haliclona caerulea: Purification and mass spectrometric characterization. Int J Biochem Cell Biol 45: 2864-2873.

Dinh Thanh Trung, Vo Thi Dieu Trang, Ngo Thi Duy Ngoc, Phan Thi Hoai Trinh, Tran Thi Hai Yen, Le Dinh Hung (2017) Haemagglutination activity of the extracts from some Vietnam marine invertebrates.Vietnam $J$ Biotechnol 15: 691-701.

Dodd RY, MacLennan AP, Hawkins DC (1968) Haemagglutinins from marine sponges. Vox Sanguinis 15: 386-391.

Dresch RR, Zanetti GD, Lerner CB, Mothes B, Trindade VMT, Henriques AT, Vozári-Hampe MM (2008) ACL-I, a lectin from the marine sponge Axinella corrugata: Isolation, characterization and chemotactic activity. Comp Biochem Physiol Toxicol Pharmacol 148: 23-30.

Dresch RR, Lerner CB, Mothes B, Trindade VMT, Henriques AT, Vozári-Hampe MM (2012) Biological activities of ACL-I and physicochemical properties of ACL-II, lectins isolated from the marine sponge Axinella corrugata. Comp Biochem Physiol Biochem Mol Biol 161: 365-370.

Dresch RR, Zanetti GD, Irazoqui FJ, Sendra VG, Zlocowski N, Bernardi A, Rosa RM, Battastini AMO, Henriques AT, Vozári-Hampe MM (2013) Staining tumor cells with biotinylated ACL-I, a lectin isolated from the marine sponge, Axinella corrugata. Biotech Histochem 88: $1-9$.

Engel M, Bachmann M, Schröder HC, Rinkevich B, Kljajic Z, Uhlenbruck G, Müller WEG (1992) A novel galactose- and arabinosespecific lectin from the sponge Pellina semitubulosa: Isolation, characterization and immunobiological properties. Biochimie 74: 527-537.

Filho SMG, Cardoso JD, Anaya K, Nascimento ES, de Lacerda JTJG, Mioso R, Gadelha TS, Gadelha CAA (2015) Marine Sponge Lectins: Actual Status on Properties and Biological Activities. Molecules 20: 348-357.

Garderes J, Bourguet-Kondracki ML, Hamer B, Batel R,Schröder HC, Mülle WEG (2015) Porifera Lectins: Diversity, Physiological Roles andBiotechnological Potential. Mar Drugs 13: 5059-5101.

Gundacker D, Leys SP, Schröder HC, Müller IM, Müller WEG (2001) Isolation and cloning of a C-type lectin from the hexactinellid sponge Aphrocallistes vastus: A putative aggregation factor. Glycobiology 11: 21-29.

Kawsar SMA, Fujii Y, Matsumoto R, Ichikawa T, Tateno H, Hirabayashi J, Yasumitsu H, Dogasaki C, Hosono M, Nitta K, Hamako J, Matsui T, Ozeki Y (2008) Isolation, purification, characterization and glycan-binding profile of a D-galactoside specific lectin from the marine sponge, Halichondria okadai. Comp Biochem Physiol B 150: 349-357.

Kawsar SMA, Mamun SMA, Rahman MDS, Hidetaro Y, Ozeki Y (2011) In vitro antibacterial and antifungal effects of a $30 \mathrm{kDa}$ D-galactoside-specific lectin from the desmosponge Helichondria okadai. Int J Biol Life Sci 7: 31-37.

Kurata O, Hatai K (2002) Activation of carp leukocytes by a galactose binding protein from Aphanomyces piscicida. Dev Comp Immunol 26: 461-469.

Le Dinh Hung, Hori K, Huynh Quang Nang (2009a) Screening and preliminary characterization of hemagglutinins in Vietnamese marine algae. J Appl Phycol 21:89-97.

Le Dinh Hung, Sato T, Shibata H, Hori K (2009b) Biochemical comparison of lectins among three different color strains of the red alga Kappaphycus alvarezii. Fish Sci 75: 723-730.

Le Dinh Hung, Hori K, Huynh Quang Nang, Tran Kha, Le Thi Hoa (2009c) Seasonal changes in growth rate, carrageenan yield and lectin content in the red alga Kappaphycus alvarezii cultivated in Camranh Bay, Vietnam. J Appl Phycol 21: 265-272.

Le Dinh Hung LD, Sato Y, Hori K (2011) High-mannose $\mathrm{N}$-glycan specific lectins from the red alga Kappaphycus striatum (Carrageenophyte). Phytochemistry 72: 855-861.

Le Dinh Hung, Bui Minh Ly, Vo Thi Dieu Trang, Ngo Thi Duy Ngoc, Le Thi Hoa, Phan Thi Hoai Trinh (2012) A new screening for hemagglutinins from Vietnamese marine macroalgae. J Appl Phycol 24: 227-235.

Le Dinh Hung, Ngo Thi Duy Ngoc, Kanji Hori (2013) Isolation and characterization of novel lectin from the red algaGracilaria salicornia. Vietnam J Biotechnol 11: 743753.

Le Dinh Hung, Hirayama M, Bui Min Ly, Hori K (2015a) Purification, primary structure and biological activity of high-mannose $\mathrm{N}$-glycan specific lectin from the cultivated Eucheuma denticulatum. J Appl Phycol 27: 1657-1669.

Le Dinh Hung, Hirayama M, Bui Minh Ly, Hori K (2015b) Biological activity, cDNA cloning and primary structure of lectin KSA-2 from the cultivated red alga Kappaphycus striatum (Schmitz) Doty ex Silva. Phytochem Lett 14: 99-105.

Le Dinh Hung, Makoto Hirayama, Kanji Hori (2016) Cloning and characterizing cDNA sequences coding high- 
mannose N-glycan binding lectins from cultivated red algae Eucheuma denticulatum and Kappaphycus striatum.Vietnam J Biotechnol 14: 327-336.

Le Dinh Hung, Tran Thi Hai Yen, Dinh Thanh Trung (2018a) Characterization of O-glycan binding lectin from the red alga Hydropuntia eucheumatoides.Vietnam $J$ Biotechnol 16: 687-696.

Le Dinh Hung, Bui Minh Ly, Vo Thi Hao, Dinh Thanh Trung, Vo Thi Dieu Trang,Phan Thi Hoai Trinh, Ngo Thi Duy Ngoc, Thai Minh Quang (2018b) purification, characterization and biological effect of lectin from the marine sponge Stylissa flexibilis (Lévi, 1961). Comp Biochem Physiol Part B 216: 32-38.

Le Dinh Hung, Le Thi Hoa, Le Nhu Hau, Dinh Thanh Trung (2019) The lectin accumulation, growth rate, carrageenan yield, and quality from the red alga Kappaphycus striatus cultivated at Camranh Bay, Vietnam. J Appl Phycol 31:1991-1998.

Mebs D, Weiler I, Heinke HF (1985) Bioactive proteins from marine sponges: Screening of sponge extracts for hemagglutinating, hemolytic, ichthyotoxic and lethal properties and isolation and characterization of hemagglutinins. Toxicon 23: 955-962.

Miarons PB, Fresno M (2000) Lectins from tropical sponges. Purification and characterization of lectins from genus Aplysina. J Biol Chem 275: 29283-29289.

Mistry AC, Honda S, Hirose S (2001) Structure, properties and enhanced expression of galactose-binding C-type lectins in mucous cells of gills from freshwater Japanese eels (Anguilla japonica). Biochem J 360: 107-115.

Moura RM, Queiroz AFS, Fook JMSLL, Dias ASF, Monteiro NKV, Ribeiro JKC, Moura GEDD, Macedo LLP, Santos EA, Sales MP (2006) CvL, a lectin from the marine sponge Cliona varians: Isolation, characterization and its effects on pathogenic bacteria and Leishmania promastigotes. Comp Biochem Physiol Mol Integr Physiol 145: 517-523.

Pajic I, Kljajic Z, Dogovic N, Sladic D, Juranic Z, Gasic MJ (2002) A novel lectin from the sponge Haliclona cratera: Isolation, characterization and biological activity. CompBiochem Physiol Toxicol Pharmacol 132: 213-221.
Queiroz AFS, Moura RM, Ribeiro JKC, Lyra IL, Cunha DCS, Santos EA, De-Sales MP (2008) Pro-inflammatory effect in mice of $\mathrm{CvL}$, a lectin from the marine sponge Cliona varians. Comp Biochem Physiol C 147: 216-221.

Queiroz A, Silva R, Moura R, Dreyfuss J, Paredes-Gamero E, Souza A, Tersariol I, Santos E, Nader H, Justo G (2009) Growth inhibitory activity of a novel lectin from Cliona varians against K562 human erythroleukemia cells. Cancer Chemother Pharmacol 3: 1023-1033.

Schröder HC, Kljajic Z, Weiler BE, Gasic M, Uhlenbruck G, Kurelec B, Müller WEG (1990) The galactose-specific lectin from the sponge Chondrilla nucula displays antihuman immunodeficiency virus activity in vitro via stimulation of the $\left(2^{\prime}-5^{\prime}\right)$ oligoadenylate metabolism. Antivir Chem Chemother 1: 99-105.

Schröder HC, Ushijima H, Krasko A, Gamulin V, Thakur NL，Diehl-Seifert B， MüllerIM， Müller WEG (2003) Emergence and disappearance of an immune molecule, anantimicrobial lectin, in basal metazoa. A tachylectinrelated protein in the sponge Suberites domuncula. J Biol Chem 278: 32810-32817.

Schröder HC, Boreiko A, Korzhev M, Tahir MN, Tremel W, Eckert C, Ushijima H, Müller IM, Müller WEG (2006) Co-expression and functional interaction of silicatein with galectin:Matrix-guided formation of siliceous spicules in the marine demosponge Suberites domuncula.J Biol Chem 281: 12001-12009.

Sepcic K, Kauferstein S, Mebs D, Turk T (2010) Biological activities of aqueous and organic extracts from tropical marine sponges. Mar Drugs 8: 1550-1566.

Sharon N, Lis H (2003) Lectins, second ed. Kluwer Academic Publishers, The Netherlands.

Xiong C, Li W, Liu H, Zhang W, Dou J, Bai X, Du Y, Ma $\mathrm{X}$ (2006) A normal mucin-binding lectin from the sponge Craniella australiensis. Comp Biochem Physiol Toxicol Pharmacol 143: 9-16.

Yousif AN, Albright LJ, Evelyn TPT (1994) Purification and characterization of a galactose-specific lectin from eggs of coho salmon Oncorhynchus kisutch and its interaction with bacterial fish pathogens. Dis Aquat $\mathrm{Org}$ 20: 127-136.

\section{HOẠT TÍNH NGƯNG KẾT HỒNG CẦU CỦA LECTIN TÙ̉ DỊCH CHIẾT MộT SỐ HẢI MIẾN VIẸT NAM}

\section{Lê Đình Hùng, Đinh Thành Trung}

Viện Nghiên cứu và Ứng dụng Công nghệ Nha Trang-Viện Hàn lâm Khoa học và Công nghệ Việt Nam.

\section{TÓM TẮT}

Dịch chiết từ 16 mẫu hải miên Việt Nam đã được kiểm tra hoạt tính ngưng kết máu với các dạng hồng cầu khác nhau của động vật và người ở dạng tự nhiên và dạng đã xử lý enzym. Mười bốn mẫu thể hiện hoạt tính 
ngưng kết với ít nhất một trong số các hồng cầu thử nghiệm, chứng tỏ dịch chiết từ $87,5 \%$ mẫu hải miên được dùng để khảo sát có hoạt tính ngưng kết với ít nhất một dạng hồng cầu. Dịch chiết từ các mẫu Acanthella cavernosa, Axinyssa sp., Cinachyrella sp., 01NT.2.4, 3.5, 3.10, 3.11 và 3.18 có hoạt tính ngưng kết mạnh với các dạng hồng cầu nhóm máu người và động vật khác nhau đã được xử lý enzyme. Trong thí nghiệm ức chế sự ngưng kết máu với các đường và các glycoprotein khác nhau, hoạt tính ngưng kết hồng cầu của dịch chiết từ Acanthella cavernosa không bị ức chế bởi các đường đơn, nhưng bị ức chế bởi porcine stomach mucin và fetuin, trái lại hoạt tính của dịch chiết từ Cinachyrella sp. chỉ bị ức chế bởi đường đơn như $\mathrm{D}$-galactose và $\mathrm{N}$ acetyl-D-galatosamine nhưng không với các glycoprotein. Hoạt tính ngưng kết hồng cầu của dịch chiết từ Stylissa flexibilis bị ức chế bởi $\mathrm{D}$-galactose, porcine stomach mucin, fetuin và dẫn xuất asialo của chúng, gợi ý sự có mặt của lectin đặc hiệu cho O-glycan trong mẫu này. Hoạt tính ngưng kết hồng cầu của 4 dịch chiết từ $A$. cavernosa, $S$. flexibilis, Axinyssa $\mathrm{sp}$. và Cinachyrella $\mathrm{sp}$. bền trong phạm vi rộng của nhiệt độ và $\mathrm{pH}$. Hoạt tính của các dịch chiết từ $A$. cavernosa, Axinyssa sp. và Cinachyrella sp. không phụ thuộc vào sự có mặt của cation hóa trị hai, ngoại trừ dịch chiết từ $S$. flexibilis phụ thuộc vào sự có mặt của cation hóa trị hai cho hoạt tính sinh học. Các kết quả của nghiên cứu này gợi ý rằng hải miên Việt Nam có thể là một nguồn lectin giá trị cho các ứng dụng trong hóa sinh và y sinh.

Từ khóa: đặc tính liên kết carbohydrate, hải miên, hoạt tính ngung kết hồng cầu, lectin 